\title{
Theology of Violence-oriented Takfirism as a Political Theory: The Case of the Islamic State in Iraq and Syria (ISIS)
}

\author{
Emin Poljarevic
}

The notion of takfir (lit. excommunication) was part of pre-modern heresiology that revolved around a range of conceptualisations of kufr (rejection of belief) and the conditions of belonging to a Muslim community (Al-Shahrastani 1923). ${ }^{1}$ This issue of religious and sectarian belonging was directly connected to belonging to a Muslim polity. Takfir, therefore, entailed pronouncing judgment on Muslims for having exited a community of Muslims either through what was understood to be their 'erroneous' beliefs and/or actions. Such judgments have often had direct political consequences (Khalidi 2005). Those who voluntarily had left Islam and, consequently, left a specific Muslim community, have traditionally been re-classified as murtaddin (apostates) and/or kuffār (non-believers, sing. käfir) (Chaliand and Blin 2007). For example, in his Incoherence of the Incoherence, the seminal philosopher and jurist Ibn Rushd (d. 1198) opined that "heretics," namely, those who violate the agreed upon principles of the divine law are apostates, ought to be killed (Khalidi 2005:167). In the classical period of Islam, the issue of excommunication has often been a complex legal discussion among Islamic scholars and philosophers.

The earliest systematic form of such theologically based excommunication appeared in the 66os, when a zealous militant opposition group of proto-Khawārij (lit. 'those who go out') or Khārijites, called upon Muslims to reject and rebel against 'Alī's political authority. The series of events within which later Khārijite theology started to crystalize is oftentimes described

1 Funding for the research for this chapter was provided by Riksbankens Jubileumsfond [NHS14-1701:1] through the project "Resolving Jihadist Conflicts? Religion, Civil War and Prospects for Peace," led by Isak Svensson, Department of Peace and Conflict Studies, Uppsala University. The author wishes to thank all those who have reviewed early drafts of this chapter. A number of people have commented and improved the quality of the text, especially Jay Willoughby, Carole Cusack, Muhammad Afzal Upal, and two anonymous reviewers. The usual disclaimers apply. 
as the first fitna (lit. ordeal). The large-scale civil war between 'Alì (by Sunnīs regarded as the fourth caliph, d. 661) and Mu'āwiya (the governor of Damascus, r. 639-68o $)^{2}$ enabled the emergence of a range of more of less theologically zealous groups, of whom the most politically significant were the Khawārij. During an arbitration attempt, a group within the 'Alī's encampment rejected any thought of negotiation based on several Qur'anic passages claiming that only God, the true Sovereign, could arbitrate between a legitimate political authority ('Alī) and the rebels (Mu'āwiya's Damascene army). This caused a serious split between 'Alì's supporters and those who rejected his attempt to negotiate (Hodgson 1974). Later, a Khārijite assassinated 'Alī with a poisoned sword in 661. A range of violent events and political rifts followed this early intra-Muslim schism.

The early Khārijites accused both parties, including each other's active and passive supporters, of heresy and apostasy. Their central axiom was expressed by Qur'ān: 12:40, which summarizes the notion of God's legislative sovereignty: lā hukm illā lillāh [legislation belongs to God alone]. In addition, their decontextual and literal reading of the text frequently pointed to the verses 4:6o, 4:100, 12:14, and similar passages, all of which in various ways express God's supremacy in making (political) judgments.

In effect, Khärijites developed theological arguments that labelled those who indirectly deny God's sovereignty to be apostates. For example, the logic of Khārijites' arguments led them to claim that if and when Muslim political leadership try to resolve political disputes by, for instance, negotiating with their opponents (that is, 'Alī's negotiation with Mu'āwiya), they are considered breaking their bond with the Qur'ānic principles of God's sovereignty, which makes them deviants and apostates who deserve severe punishment. The result has therefore been that Khārijites considered it a religious duty to fight all Muslim political leaders and, indeed laymen, who neither joined nor swore allegiance to the Khārijites. For instance, the early Khārijites labelled the Mu'tazila 'deviants' because they chose abstention (itizāl) when confronted with the choice between 'Alī and Mu'āwiya (Adang and Ansari 2015).

The early late-seventh century Khārijite movement represents an early violence oriented and literalist interpretative tradition that justified rebellion as the religious tradition's central tenet. Comprised of relatively small groups of ardent rebels scattered across Iraq, Iran, the eastern Arabian Peninsula, and the Maghreb region, they sought political power to 'purify' Muslim communities primarily through literalist and selected reading of the Qurānic text

2 Sunnī Muslims consider both as the Prophet's Companions who led the opposing sides in the first Muslim civil war over a legal issue related to the murder of Caliph 'Uthman ibn al-'Affan in 656. 'Alī was the Prophet's cousin and son-in-law. 
and prophetic narrations. For instance, to qualify as a political ruler, a Muslim must demonstrate extraordinary moral virtue, justice, religious devotion, and knowledge, as well as strictly apply the appropriate legal sanctions to those who break Islam's moral code. The entire debate on distinctions between major and minor sins, ethics, and moral virtues within the early mainstream Sunnì scholarship seems to have evolved in an attempt to counter what was considered to be Khārijites' unreasonableness. The debate evolved in the light of the formation of interpretative methodologies and scholastics used by the main part of the religious scholars primarily within the Muslim urban centres.

Some of the main concerns articulated by Khārijites is that any violation of moral codes unequivocally identifies the political leader and his supporters as non-Muslims - which would theologically require all Muslims to rebel against such a person's authority (Kenney 2006). However, it is rather unclear who is responsible for making this decision: the majority of male adults, the whole community of believers, the religious authorities, or any individual who has a 'legitimate' cause? This particular question has also been a source of intense controversy regarding IsIs' proclamation of its caliphate on 29 June 2014 (Gerges 2016).

Nonetheless, insisting upon the 'correctness' of a person's actions also indicated that the Khārijites emphasised free will far more than did the early Sunnīs, especially the Hanbalīs, who were leaning more towards predestination. This theological distinction became clearer during the tenth century, after the great ninth-century rivalry and conflict between Ash'arì/Hanbalì and Mu'tazilite scholarship (Makdisi 1981). The later Khārijites' strict adherence to inflexible legal requirements and high moral expectations, particularly for political leaders, meant that group cohesion of and within their various groups slowly eroded. Simply put, the severity of their socio-political structures and codes of conduct was, in the long term, untenable and thus caused an increasing variety of reinterpretations of alternative theological principles to emerge.

The initial severity of differentiation between 'believers' (Khārijites themselves) and all others (kuffär) was therefore revised. For instance, the outright hostile and violent othering and mass killing (istirāo $\mathbf{d})$ of non-compliant Muslim 'infidels' (kuffār and murtaddīn) turned into nonviolent labelling, wherein general Muslim public were categorised as hypocrites, 'the ungrateful ones', heretics, and so on. These and similar reinterpretations caused many additional (but smaller) groups to appear, often named after their originators such as the Azāriqa, 'Atāwiyya, Baihāsiyya, Ibāḍiyya, Muhakakima, Najadāt, and Zafariyya (Al-Shahrastani 1923). Only a few of these have survived. The Ibadis, one theologically and politically reformed Khārijite group, eventually became the official religious establishment of the Sultanate of Oman (Kenney 2006). 
Both Sunnī and Shīì groups have used takfir (excommunication) throughout Islam's multivariate history. For example, its theological and jurisprudential application played a significant political role during the Mu'tazili mihnna (ordeal or inquisition) of the 83 os and 840 os in what is today known as Iraq against Hanbali and other rival Islamic scholars. The irrecoverable end of $\mathrm{Mu}$ 'tazilism as a religious and intellectual force came only after the political shift of power (Makdisi 1981). Others examples are ibn Taymiyya's (d. 1328) Mardin fatwā against Syria's Mongol rulers; the Șafavid (Shīīi) Akhbāriyya's takfir of Muslim philosophers in the 16oos; and most notably, during the 170os, the religious movement of Muhammad ibn 'Abd al-Wahhāb's en masse excommunication of the Sunnī Ottoman and Shīī religious leaders. All of these and similar historical cases are either concerned with othering their doctrinal and/ or political opponents, who are perceived as violating 'Islamic doctrine's fundamental principles' and thus as not belonging to the broader community. Again, such theological exclusions often had socio-political consequences that largely depended upon the context or the dynamics of pre-existing religious polarisations as well as the political authorities' interest, willingness and/or ability to support the 'orthodox' position vis-à-vis the perceived heterodoxies (El-Rouayheb 2015).

\section{$2 \quad$ Political Theory of Loyalty and Disavowal}

The idea of political and religious allegiance was hotly debated among Sunnī scholars throughout the classical period (ca. 85os-140os) (Al-Mawardi 1995). Sunnī polemics largely revolved around consistency in a person's theological, jurisprudential 'belonging', which in turn determined that person's social and political rights vis-à-vis leadership and other religious communities. Such polemics became more contentious in Muslim polities with higher levels of theological heterodoxies. For example, the survival of four schools of Sunnī jurisprudence (Mālikī, Shāfì̄i, Ḥanbalī, and Ḥanafì) and the dominant Shī'ī school of jurisprudence (Ja farī) is a consequence of complex relationships between political and scholarly classes in pre-modernity. One suggestion is that the crystallization of these schools and the de facto disappearance of the Zahiris and a significant number of other jurisprudential traditions is a direct result of political decisions from the early thirteenth century onwards (Makdisi 1981). Similar developments occurred later on in the North Africa, Levant, Arabian peninsula and in the eastern lands of Islam (Hodgson 1974). Nevertheless, the broader Sunnī establishment drifted towards a more pragmatic compliance and coexistence between the religious scholar-experts class and the political leadership (El-Rouayheb 2015). 
For example, the long-term scholarly discourse drifted towards religious understandings that the populations were expected to obey a political leader who publicly proclaims (shahāda) God's unity and, at least in theory, admits the sovereignty and supremacy of God's will over his own dominion (Hodgson 1974). This requirement entailed public announcements of loyalty, during the congregational Friday prayers and on other occasions, to a political leader or religious establishment ('ulam $\bar{a}$ ) either as a matter of conviction or coercion. It is therefore not surprising that the classical Sunnì scholarly deliberations from the tenth century onwards focused primarily on a political ruler's legitimacy and discouraging popular rebellions (ahkām al-bughāh) against political leadership (Abou el-Fadl 2001).

The basis and framework of political commitment and legitimacy (siyāsa shariyya) remained at the heart of classical scholarly discussions on political theory related to caliphal authority and legitimacy (Hodgson 1974). That is different from the idea of al-wala $\vec{a}^{2} w a-l-b a r \bar{a}^{3}$ (loyalty and disavowal) within the modern discussion concerning political legitimacy brought forth by contemporary Salafi interlocutors. Muhammad Saeed Al-Qahtani (b. 1956) presents one of the most comprehensive contemporary Salafi-discussions of that topic. He, along with other Salafi interlocutors, conceptualizes this idea as a primary duty of contemporary Muslims, one that entails a personal commitment to a relationship with God, a social framework that enables the fulfilment of collective duties, and a political dimension that involves prospects of violence (Al-Qahtani 2003). Most of the pre-modern conceptualisations of political commitment were not necessarily framed in the terminology of al-wala $\vec{a}^{\prime} w a-l-b a r \bar{a}$, but the insinuations of allegiance and political compliance were nevertheless deeply imbedded in the discourse.

Historically, the scholarly elites ('ulamă') were forced to respond various political circumstances and conflicts with moral, ethical, and political opinions on how socio-political problems ought to be addressed. For instance, the early proto-Sunnī scholars proclaimed the Khārijites unbelievers (de facto excommunication) because they posed an imminent threat to the existing social order. Today, there is a similar situation where mainstream Muslim scholars disqualify Is Is' leadership as de facto apostates (see below). Arguably, the general Sunnī opinion held that rebels destabilise ruling structures, which, in turn, results in social and material destruction and, subsequently, causes violations of both the rights of God (huquq Allāh) and the rights of Muslims (huquq al-ibād). Shī̄ì scholars developed a theological principle tawallā (pledging allegiance to the ahlal-Bayt) and tabarrā (displaying enmity towards the enemies of God, the Prophet, and his family).

In the classical period, however, the early Hanbalīs and similar contemporary proto-Sunnīs expressed predominantly negative opinions regarding the 
meaning of al-wala $\bar{a}$ wa-l-barä. Their main understanding was that the formulation of loyalty and disavowal is a religious innovation caused by sectarian infighting, which many Ḥanbalīs interpreted as religious deviancy. Nonetheless, a violation of the principle of ('correct') political and/or religious allegiance in the subsequent centuries would occasionally result in occasional excommunication of a Muslim individual or group (Adang and Ansari 2015). Such pre-modern doctrines of othering or identity affirmation and differentiation played an important and historically contingent role in othering of thought heretics.

Distinctions between the in- and out-group members were often manifested through context-dependent processes of social classification, political belonging, and legal status. Similar distinctions acquired new meanings during European colonialism and/or nation-state formation (Lewis 1988). During the first half of the twentieth century and within the context of unravelling colonial control, modern national state formations, growing nationalism, panArabism, secularism, the declining relevance of religious institutions, and the evolution of authoritarian regimes gave takfirism its new form and means of expressing it.

The traditional distinction between believers and non-believers was for the most part a non-political issue in the MENA (Middle East and North Africa) region during the Ottoman political hegemony. There were few political repercussions for apostasy on the local level (Deringil 200o). Nevertheless, a secularized form of takfirism (for example, disqualifying and expelling a person as a member of a community) arose and dominated all public and political discussions in determining a person's legal status vis-à-vis a state or citizenship. Such belonging was oftentimes expressed through narratives of more or less intense expressions of patriotism, including ancestral and ethnic belonging. Hence, we find Sunnī citizens in Iran or Shī̄ì citizens in the Gulf monarchies. In the case of reformed Khārijites, such as Oman's Ibāḍī Muslims (or Muhakkkima as some prefer to be called today), takfir has also appropriated a new largely abstract meaning of excommunication, that is based on symbolic confined to differentiations between the larger body of Muslims (considered by and large as hypocrites) and the 'true' believers.

\section{Belonging between State Sanctioned Nationalism, Ethnocenticity and Religious Communitarianism}

Some would argue that takfirism during the latter half of the twentieth century has evolved into a contentious religious and political issue due to the failure of 
pan-Arab nationalist projects across the MENA region (Ibrahim 2007). Within this process of conceptual evolution, terminology such as al-walä wa-l-baräa came to play an increasingly central role in religio-political othering. For example, the early modern interpretation of political loyalty and disavowal within the national state framework was largely interpreted as a subordinate issue of religion $(f u r \bar{u})$, namely, political allegiance to a nation constructed within specific territorial borders. As a range of initially vibrant nationalist projects turned into authoritarian military and monarchic systems, a significant part of political opposition and intellectual elites turned towards cultural and religious symbols for inspiration (Hourani 1970). A part of more militant and religiously inspired opposition groups and several regimes in Muslim-majority states began interpreting and promoting political loyalty as an essential part $(u s ̦ \bar{u} l)$ of the Islamic creed, thereby merging and equating belief in God with loyalty to a particular political order. Such conflation of political and religious terminology has been expressed through political narratives by which some authoritarian regimes and militant opposition groups seek to delegitimise their respective political opponents.

During the last half of the twentieth century seemingly marginal political oppositional groups in the MENA region picked up the idea of takfir. The first generation of modern-day violence-oriented takfiri groups operationalised al-wala ${ }^{3}$ $w a-l-b a r a \bar{a}$ as an ideological framing by which to establish a range of violent action plans against the region's authoritarian regimes. These groups confronted these regimes' repressive policies and the perceived ungodliness that their political systems represented (Kenney 2006) with violent and nonviolent mobilisation strategies. These early conceptualizations of takfir integrated the modern political idea of a nation state with the pre-modern religious doctrinal claim of God's sovereignty. For instance, divine sovereignty trumps any worldly authority claimed by modern nation states, for God's supreme will, as understood to have been recorded in the Qurān and the canonical hadith literature, is attempted to be realized in the social, political, and broader civilisational spheres. At the same time, this political reasoning had dismissed the authority and legitimacy of the traditional Islamic religious establishment's scholarship (Huwaidi 1988).

Sayyid Quṭb, Egyptian intellectual and activist, executed by the Egyptian government in 1966 allegedly for conspiring to assassinate Gamal Abdel Nasser, is presented as an political voice that provided important arguments to the later development of takfiri political doctrine (Wright 2006). One of the most important arguments in his last book, Milestones (1990), is that the "Muslim World"—a civilisational category—suffered from the overpowering social disorder that he termed "the state of jähiliyya," much like the situation in pre-Islamic Arabia. One of his suggested prescriptions to resolve this was to 
establish just governance in Muslim-majority societies based on God's sovereignty (hâakimiyya) (Quṭb 199o).

Takfir-oriented political opposition groups adopted this basic set of arguments and regarded hākimiyya as a form of operationalised al-wala $\bar{a}^{\top} w a-l-b a r \bar{a}^{3}$ within political context of a nation state. This view gave the idea of loyalty and disavowal doctrinal content and a more concrete relational link between the political and theological. As a central tenet of Islamic doctrine on par with God's unity, names, attributes, and lordship, it provided a theological argument to advocate rebellion and insurrection against perceived ungodliness and apostasy of political leadership in Muslim majority polities (Al-Maqdisi 1984). Muslim political authority, according to this view, must be based on doctrines presented in the Islamic scriptures and historical examples that had validated, during brief moments of the first Islamic century, how to govern a Muslim community and polity.

This line of theological reasoning lays ground for broadening the concept of Islamic worship ('ubüdiyya), wherein the political is an integral part of human compliance with divine purpose. In addition to broadening the role of free will by implicitly suggesting that humans are able to act/choose within the range of multiple God-given futures, these broadened understandings provided a tacit intellectual platform to reactionary theological attitudes that have potential to legitimate political violence. This is a major point of difference between violence-oriented takfirist groups, traditional Sunnī scholarly discourses and democratically inclined Islamist reformist movements.

For example, political and social movements such as the Muslim Brotherhood have denounced and rejected similar takfiri interpretations of Quṭb's original analysis and proposed reformist solutions by not employing al-wala $\vec{a}^{\prime}$ wa-l-bara $\vec{a}^{\prime}$ or hăkimiyya in their mobilization discourses and activism (Al-Hudaybi 1977; Poljarevic 2012). It is therefore significant to note that disagreements between nonviolent and violent, democratic and nondemocratic, including what is sometimes considered theologically heterodox and orthodox Muslim political and religious groups, are rooted largely in theological interpretations, ideological preference, operational disagreements and collective proclivities towards political violence or nonviolence (Hamid and Farrala 2015). One important theological feature of these disagreements is the role and meaning assigned to Islamic eschatology.

A part of the second generation of violence-oriented takfiri groups emerged during the early 1970s as a direct response to the Egyptian state's initial 
permissiveness and latter repression of selected parts of the religiously motivated political opposition. By the mid-197os, Takfir wa al-Hijra, initiated by Ahmad Shukri Mustafa (executed 1978) and others, had begun a violent campaign against state officials and institutions (Ashour 2011). By the late 1970s and early 1980s Islamic Jihād, then led by Muhammad 'Abd al-Salam Faraj (executed 1982), became the most influential promoter of takfiri militancy. His important The Forgotten Duty (farịdah al-ghäibah) had a significant effect on legitimating violence against such leaders as Anwar Sadat, who was assassinated by Faraj's group in 1981 (Faraj 2000). Another relevant argument was anchored in the fatwās of 'Umar 'Abd al-Rahman, the theological and jurisprudential council to Faraj and Islamic Jihād (Faraj 1986) which differed considerably from those of al-Azhar's scholarly elite. 'Abd al-Rahman died in a US maximum security prison in 2017, convicted in 1995 for his leading role in the 1993 World Trade Center bombings.

One of The Forgotten Duty's most important doctrinal points is the importance of waging a physical (as opposed to a spiritual) war against the perceived enemies of Islam and Muslims. Some authorities considered this a collective duty (fard kifäya), Faraj and others argued that it is an individual duty (fard 'ayn) ('Azzām 1985). The latter argument added a new sense of urgency, especially to young predominantly male audiences, for it meant that no permission was needed from political, religious, or parental authorities to join Islamic Jihād and similar groups (Cook 2011).

In the late 1970s, and as a part of the third generation of violence-oriented takfiri activism, on the first day of the Islamic year 1400 (20 November 1979), a millenarian group composed largely of university students led by Juhayman al-'Utaybī (executed in 1980) launched an armed raid and captured the Sacred Mosque in Mecca. The rebels proclaimed a new political and spiritual order in Saudi Arabia by announcing the arrival of the Mahdī, an eschatological figure who, according to most Sunnī theological interpretations, will appear some time before the Day of Judgment and lead Muslims in the global struggle for justice and salvation. Although not a new phenomenon, this type of 'mahdism' had a more innovative dimension: the particular Salafist interpretation and the nature of its threat to an important segment of the Arab political context (Voll 1982). Al-'Utaybī announced that the kingdom's clergy or for that matter any Muslim who defended the ruling system, as well as its policies and political authorities, had abandoned their religious obligations and personal piety to the extent of actual kufr, or disbelief. These and similar contemporary examples of modern-day political rebellion demonstrate both the potency and longevity of this form of political othering and its ongoing important doctrinal role in mobilising against primarily authoritarian regimes in and beyond the MENA region. 
Doctrinally, Islamist, Salafi, and other Muslim activist groups are divided along different strategic considerations some of which are outlined above, but, more importantly, along interpretations of the role of God's sovereignty, as well as how, where, and to what extent Muslims should be involved in governance (Meijer 2009). These doctrinally and subsequent jurisprudential differences in interpretation are contingent on the particularities of the surrounding political, social, and cultural contexts. Eschatological urgency is, for example, a more pronounced feature of violent groups such as ISIs, wherein the political governance of khiläfah is directly related to fulfilling an important theologically defined precondition of the Judgement Day (Dabiq 1:21-28).

Although takfirism and Salafism share important theological and legal principles, among them a literalist approach to the scripture, strict personal pietism, and demands on a public obligation-based approach to lived Islam, they do differ in significant ways. For example, Isıs' brand of takfirism stands for perpetuating violence based on the unremitting excommunication of its opponents and its ambition to establish a state as the primary mean to usher in the apocalypse. Arguably, these and other primary objectives can be considered as significant discrepancies from what has traditionally been viewed as Salafism: a diverse set of religious and ideological principles driven by ambitions to purify and authenticate Muslims' beliefs and practices (Meijer 2009).

Contemporary Salafism, broadly understood, is a wide-ranging, ultraconservative, and complicated revivalist/reformist religious methodology that has been developing more systematically since the turn of the twentieth century. Looking beyond these 'family resemblances', Is Is represents anti-systemic mobilization and violent forms of othering against all perceived enemies, which is more in line with the early Khārijites' fervent anti-establishment militancy and theological hairsplitting. Consider, for instance, its selective doctrinal positions, the level and form of repression in the state or region it controls, a place's demographic composition, the dynamic of historical grievances, along with political and religious freedoms, including the availability of a charismatic leadership and other socio-political conditions such as foreign military occupations.

\section{5}

\section{Trajectories of Violence in a Volatile Geopolitical Context}

Few violent events, besides wars, so clarify the separation between enemies. The 1979-1989 Afghan war of liberation from Soviet occupation, one such event, provided an exceptional opportunity for violence-oriented MENA region Salafi activists, some of whom already held takfiri predispositions, to defend fellow 
Muslims. Doing so enabled them to demonstrate both the theological obligation to use violence to show solidarity with their perceived religious brothers and sisters and their commitment to violent struggle beyond their own sociopolitical contexts. Subsequently, the Mujahideen gathered Arab volunteer fighters, together with parts of the organised Afghan resistance, partly under the leadership of 'Abdallāh 'Azzām (d. 1989). ${ }^{3}$ Their guerrilla tactics and tenacious insurgency led the Soviet forces to withdraw in 1989 (Kepel 2006). Other important components that helped maintain the Mujahideen's efficiency were the financial and logistical support, including the weapons and communication equipment, provided by Saudi Arabia, the United Arab Emirates, Pakistan, the United States, and others (Roy 1995).

'Azzām, one of the rare religious scholars who actually fought there, had published a range of writings during the 1980s that advanced Qutb's thesis on the urgency of action (jihād) against the perceived enemies of God and the Muslims. His theory's central tenet was that all Muslims (collectively) were theologically obliged to undertake an armed struggle against immediate injustices to confirm their Islamic commitment (Lawrence 2005). Informed by mainstream pre-modern Sunnī religious scholarship, 'Azzām presented relatively few and largely undeveloped takfiri positions in relation to the broader Muslim populations.

By the end of the 1980s, when the Soviets gradually withdrew, Usāma bin Lādin (assassinated in 2011), along with several of his companions including 'Ayman al-Zawāhirī (b. 1957), sought to maintain the foreign volunteer's momentum of military success by establishing al-Qācida (the Base) network (Farrall 2011). They had organised a transnational network to connect all of the committed, proven, and trustworthy Arabic-speaking militants (Roy 1995). At its core, the network would be hierarchically structured and headed by bin Lādin. Affiliated subsections were given operational independence but had to commit to following the general direction and principles of the central leadership and its consultative council of veteran, trusted, and personally interconnected violence-oriented activists (Gunaratna 2002). At the same time, Abū Muhammad al-Maqdisī (b. 1959), 'Umar 'Abd al-Rahman, and other allied religious scholars who have been either directly or indirectly affiliated with al-Qâ'ida and have influenced the network's doctrinal orientation demonstrated stronger tendencies to excommunicate and justify violence against political opponents, Muslim and non-Muslim alike (Farrall 2011).

3 The official name of the managing organization for the volunteers was the Service Office for (Foreign) Fighters, Maktab al-Khidmah li al-Mujahidīn. 
At the end of the Cold War and witnessing the MENA region's unravelling geopolitical structure, al-Qā̄ida's leadership adopted new ambitions, one of which was to become an independent military force capable of operating internationally. Embolden by the network's military successes in Afghanistan, bin Lādin, had offered the group's military aid to the Saudi monarchy in 1991, which felt threatened by Saddam Hussein's invasion of Kuwait. One of his supporting arguments was that al-Qāiida had overpowered a far stronger enemy, namely, the USSR, just a couple of years earlier. The Saudi leadership, however, briskly rejected his offer and turned to the United States for military support, all of which was supported by the Wahhābi religious establishment.

President George H. W. Bush responded by establishing military bases, to which he sent over half a million US soldiers, in and around the "Land of the Two Holy Places” (Mecca and Medina). Bin Lādin, along with al-Qā'ida's leadership and religious advisors, saw this as doctrinal and political treason of what is understood as Islam's principles (Hamid and Farrall 2016). Their political conclusion was similar to that of al-'Utaybī: Attack the House of Saud and its allies by all available means.

In the late 1980s and early 199os a series of civil and occupation wars in Afghanistan, Algeria, Bosnia (Croatia/Serbia), Chechnya (Russia), Iraq (the United States), Mindanao (the Philippines), Somalia, Tajikistan, and elsewhere prompted the leadership to dispatch several of its affiliates to some of these hotspots to assist the indigenous Muslim groups' war efforts (Ashour 2011). During this same period, the increased systematisation of takfirism both as a network-based violence-oriented transnational rebel-force and as a selfreferential and theologically autonomous tradition also started to assume a more distinctive ideological shape.

Al-Maqdisī, a Jordanian who as a young man knew al-'Utaybī, has been among the most important intellectuals who formulated the new meanings for takfir (excommunication), al-walä wa-l-barä (loyalty and disavowal), the nature of the relationship between belief and political action, and other notions that became pivotal concepts for takfirì militants (al-Maqdisi 1984). His contribution has been crucial to extending the meaning of historically contingent terms by weaponising them against apparent socio-political injustice, corruption, repression, and perceived godlessness in various Muslim-majority contexts. He made a particular effort to explain the meaning of hukm Alläh (God's rule), which he related to the political leadership's responsibility to rule in accord with a strict reading of scripture (Wagemakers 20o9).

For al-Maqdisī, excommunication was directly reserved for 'ungodly' political leaders. According to him, any political leader who consciously fails to 
execute his "godly" responsibility of establishing hukm Alläh as the primary symbol of recognising God's sovereignty over all things becomes a țäghüt, defined as a tyrant similar to the Pharaohs of ancient Egypt. Other prominent ideologues, such as Sayyid Imam al-Sharif (b. 1950) and Abu Mus'ab al-Suri (b. 1958), earlier presented similar arguments, but stopped short of excommunicating entire Muslim populations. This line of reasoning differs from the general theological principles of the historical Khārijites as well as those of ISIS. In the case of ISIS, the processes of excommunication become the defining feature of the group's identity and cornerstone of its organizational theological principles and eschatology that is wedded with its violence-oriented mobilization and political ambitions.

Al-Maqdisis's religious training, which consisted of the Salafi religious methodology of reasoning and a long record of social activism, for which he had been repeatedly jailed by Jordanian authorities and something that had contributed to his scholarly reputation and authority. His writings became particularly salient among personalities such as al-Zarqawi, who was already involved in ongoing violent conflicts in primarily Iraq. Although he is not a member of the al-Qā'ida network, Al-Maqdisī had provided important religiously informed arguments and personal integrity — both of which the network has utilised enthusiastically (Hegghammer 2009).

Even though al-Qā'ida and its affiliates are theologically wary of proclaiming general Muslim audiences to be non-believers, they have been more inconsiderate when it comes to using indiscriminate violence against their perceived enemies. For example, they have often justified such campaigns on the grounds of revenge, where the collateral damage is acceptable because they are attacking hostile governments or their military forces (Chaliand and Blin 2007). Such legitimation is frequently expressed in jurisprudential language, although they regularly sidestep mainstream Sunnī legal methodology and jurisprudence in favour of the operational circumstances in making strategic choices (Maher 2016).

One can reasonably argue that this violence is far closer to the violent strategies of the pre-modern Khārijite insurgency than the pre-modern Sunnī definitions of jihād as 'just war' (Poljarevic 2018). For instance, the al-Q⿱ā'ida leadership's decision to violently confront the Saudi monarchy was based primarily on the king's outward and direct hostility towards the network and its agenda, and secondarily on theological principles (Gunaratna 2002). The leadership legitimised the subsequent violence, including its attacks of nonmilitary targets, primarily as a matter of 'personal grudge' and only later as a matter of theology. 
In the mid-199os, bin Lādin sent a letter to Saudi Arabia's Council of Senior Scholars, then under 'Abd al-'Aziz bin Baz's (d. 1999) leadership, in which he outlined his criticism of the kingdom.

This aggression has reached such a catastrophic and disastrous point as to have brought about a calamity unprecedented in the history of our umma, namely the invasion by the American and western Crusader forces of the Arabian peninsula and Saudi Arabia, the home of the Noble Ka'ba, the Sacred House of God, the Muslim's direction of prayer, the Noble Sanctuary of the Prophet, and the city of God's Messenger, where the Prophetic revelation was received.

This momentous event is unprecedented both in pagan and Islamic history. For the first time, the Crusaders have managed to achieve their historic ambitions and dreams against our Islamic umma, gaining control over the Islamic holy places and the Holy Sanctuaries, and hegemony over the wealth and riches of our umma, turning the Arabian peninsula into the biggest air, land, and sea base in the region.

LAWRENCE 2OO5: 15-16

This diagnostic analysis of the perceived moral hubris of both the Saudi state and the MENA region more generally also reveals the urgency with which the revolutionary militants more broadly understand socio-political realities. For instance, using "unprecedented," "aggression," "invasion," and "Crusader forces" in relation to Islam's holy places all point to the need for immediate action. This and similar passages in his letter and later statements emphasise the foreign "control over the Islamic holy places," which call for launching a total war primarily against the monarchy and its supporters (Khatab 2011). The concept of umma, therefore, becomes a useful symbol by which to address non-Arab audiences. However, if the masses were to support such a call to arms, which is apparently important in creating permanent socio-political change, bin Lādin also had to emphasise that he had the backing of the region's senior and influential Salafi scholars (Ibrahim 2007).

Such a line of argumentation is largely compatible with the thought of 'Azzām, who promoted a form of religious legitimacy anchored in the theological discourse of contemporary Salafi and Wahhābi religious scholars. This approach is also emblematic of foreign volunteers in the Afghan war of 1979-1989, a process of which bin Lādin himself is partly a result of (Bergen 2006). However, both he and al-Ẓawāhirī (b. 1951), now the first in command of the al-Qā'ida network, widened 'Azzām's approach. Bin Lādin's understanding of violent opposition 
and warfare was anchored in the militant Salafi activist empowerment discourse that engaged in what can be described as a "civilisational struggle for survival," a trend that can be traced to the Muslims' struggles against colonialism during the twentieth century. On the other hand, he sought theological recognition and legitimation from recognised Salafi, Wahhābi and other Sunnì scholarship to communicate with the masses in Muslim majority sociopolitical contexts (Lawrence 2005).

al-Ẓawāhirī, a founding member of the small Egyptian militant group Islamic Jihād and a part of the second generation of violence-oriented takfirism, had a clear ideological and strategic vision that entailed a violent overthrow of what he and his co-founders considered heretical Arab regimes. His vision and leadership has consistently been more takfiri-oriented than bin Lādin's, who emphasised a more theologically reconciliatory approach to the general public, including religious tolerance of Shīiss living in Afghanistan and the MENA region. This public communication strategy of addressing particular religious and political authorities has, at times, been both strategically functional and morally resonant with vast segments of frustrated and politically perceptive young men primarily in that region. Al-Qā'ida gained little physical support for its efforts, however, and its network eventually became a distinctive transnational symbol of radical resistance against the U.S. interests there, and its repressive regional allies (Gerges 2009).

One of the major features of al-Qā'ida's political theology, as it relates to other political opposition groups in Muslim-majority societies, is its insistence on creating a radically different transnational political space. Such an approach entails more distinctive features than what is sometimes described as 'jihädi-Salafism', which is closer to the contingent reading of the neoclassical doctrine of $j i h \bar{a} d$ (Maher 2016). One classical understanding dictates a broad religious scholarly support for violent action in a particular territory, which is, in turn, based on the request of that territory's political leadership for military aid. Thus, it can be argued that al-Qā'ida gradually developed a distinct form of ideological and strategic mobilisation that did not fully resemble that of 'Azzām, which was more in line with the neoclassical doctrine of jiha $\bar{a}$. This gradual transformation occurred primarily due to the recruitment of an increasing number of younger takfiri-oriented activists from Egypt's Islamic Jihād (led by al-Ẓawāhirī), as well as Algerian and Libyan militants who had little interest in discussing theological methodology beyond its violent interpretations. Al-Qā'ida's political theology therefore represents an organisational and doctrinal kernel out of which IsIs developed. 
The third generation of violence-oriented takfiri mobilization was born after $9 / 11$. This critical event has had irreversible effects on the MENA region and indeed on large segments of Muslim-majority societies. The invasion of Afghanistan by the US and other forces in late 2001 and dispersal of al-Qā'ida's infrastructure there was one immediate result. A far more substantial one was the US invasion and subsequent occupation of Iraq in early 2003. The occupation's initial result - the total collapse of Saddam Hussein's Baathist state institutions - created opportunities for al-Qāiida to enter a new battlefield with a renewed sense of self-importance (Gerges 2016).

Abu Bakr Naji (d. 2008), a little-known al-Qā'ida operative who authored The Management of Savagery: The Most Critical Stage through Which the Umma Will Pass (Idārah al-tawāhush: akhțar marḥalah satamurru bihā al-'ummah), argues that the ultimate goal of the violence-oriented takfiri $\left(\mathrm{s}^{\prime}\right)$ struggle is to create and promote total war against all perceived enemies both locally and globally. Naji represents the fourth generation of violence-oriented takfiri militancy. In such a situation, the ensuing savagery and destruction would offer Muslim populations little choice other than to view joining them as the only way to establish security and stability. This influential text recommends ways to institutionalize takfirism within the scope of a modern (also global) state. Its apocalyptic message focuses on conquering and gaining support from 'disillusioned' Muslim populations. In short, by drawing the US and the EU into wars against Muslim-majority states, a large swath of populations would 'realise' who the cosmic enemy is and thereafter join the struggle to establish the caliphate (Naji 2004). Naji's text outlines a grand political strategy without extensive theological discussion, an approach that appeals to a new strand of violence-oriented takfiri activists who are arguably less competent in following or even interested in complex theological explanations and methodologies. ${ }^{4}$

Al-Qā'ida gradually adopted the Jordanian takfirì militant Ahmad Al-Khalayla, better known as Abu Mus'ab al-Zarqawi (d. 2006), as its network's leading member in Iraq. Much like Naji, he can be considered representative of the fourth generation of violence-oriented takfiri militancy. In the early 2003, his Group for Monotheism and Jihād (Jamāat al-Tawhīd wa al-Jihād) was on al-Qāaida's probation. However, the group quickly proved to be an effective insurgent group that could not be ignored, and thus became a primary, although disorderly, al-Qāiida affiliate. In 2004 it adopted the name

4 Funding for the translation by W. McCants was provided by the John M. Olin Institute for Strategic Studies at Harvard University. 
the al-Qā'ida Organisation for Jihād in the Land of Two Rivers (Tanzīm Qā'ida al-Jihād fì Bilād al-Rafidayn), or simply al-Qā'ida in Iraq (AQI). Its primary goal was to simultaneously target the occupying forces and the Shi`a-dominated government, along with Shía civilians and especially their religious symbols and gatherings (Celso 2015). Al-Zarqawi, an earlier student and colleague of al-Maqdisī, implemented some of the takfirì theological teachings after significant recalibration of exactly who was 'the enemy'. According to its subsequent widening and weaponising of al-Maqdisī's scriptural interpretations, any Sunnī who opposed AQI and essentially all Shīa Muslims were legitimate targets. Subsequently, al-Maqdisī sought to distance himself from such indiscriminate violence by openly disagreeing with his former student on both theological and jurisprudential grounds.

Another theological feature of al-Zarqawi's militancy was his ardent focus on eschatology, particularly on the smaller and larger signs of the Day of Judgment ('alamāt al-sa'ā al-sughrā wa al-kubrā). One of his emblematic statements, uttered sometime between 2003 and 2006, was: "The spark has been lit here in Iraq, and its heat will continue to intensify-by Allah's permissionuntil it burns the Crusader armies in Dabiq." This eschatological message, a permanent feature of the Is Is' flagship publication Dabiq, appears on either first or second page of each issue of the magazine, ${ }^{5}$ thereby signalling the importance and centrality of al-Zarqawi's mission, mobilisation narrative, and a subsequent feature of IsIs' takfiri doctrine (McCants 2015). It is based on a reading of what is sometimes described 'as a minor sign of the Apocalypse' in Sunnì eschatological thought. This is a part of a well-known Prophetic statement recorded in Șahịh Muslim's "Book of Tribulations and Portents of the Last Hour," it reports that the Prophet had said that: "The Last Hour will not come until the Romans land at al-A'maq [in present-day Turkey] or in Dabiq [in present-day Syria]." This is an important example of invoking prophetic insights and the direct implications of representing the divine order. This type of messianic and apocalyptic appeal to wider audiences is an important ISIS mobilization strategy.

Al-Zarqawi did not live to see the formation of the Islamic State in Iraq in 2010, its 2014 declaration of reinstatement of caliphal authority, its violent campaigns, institutional development, and temporary revivification of slavery, ultimately its military decline and 2019 collapse. Nevertheless, the significance

5 Fifteen issues of this magazine were published during 2014 and 2016, often distributed via the deep web. The featured contents ranged topically from news reports from a range of battlefields, interviews with Isis soldiers and leaders, as well as doctrinal memoranda, including a recurring and distinct eschatological message. They have, at present, no stable URL or online location. 
of his interpretation of takfiri doctrines, strategy of indiscriminate violence, and emphasis on eschatology can be seen as central to IsIs' establishment. On the other hand, these important components were among the key causes of the ISIs-al-Qāiida split in 2014 (Celso 2015).

For instance, much in line with al-Maqdisis's (part of the second-generation of violence-oriented takfirī thinkers) critique, al-Qāiida's leadership repeated attempts to reign in al-Zarqawi by ordering him to stop attacking general populations and focus instead on the occupying troops. But he continued and even intensified his group's violent campaign; a clear violation of his earlier pledge of obedience and allegiance $\left(\right.$ bay $\left.^{\prime} a\right)$ to bin Lādin. This violation has oftentimes been interpreted as a breach of a fundamental theological commitment and therefore equated with apostasy, which in this case did not result in enmity and violence. In the case of the ISIs' interpretation the principles of bay'a this is understood to mean total obedience to the caliph.

Although troubled by al-Zarqawi's decision, al-Qācida's leadership never severed contact with him or denied him support, indicating that their theological pragmatism was tied to their political and strategic realism. Despite the ensuing criticism, his group's brutality and rebellious effectiveness attracted large numbers of recruits and media notoriety. Some estimates have shown that he commanded only a few dozen militants at the beginning of the US invasion in 2003 - a number that had grown to several thousand rebels and tens of thousands of supporters just a few years later (Gerges 2016). It can therefore be argued that the nature and brutality of al-Zarqawi's violent strategy and strict takfiri doctrine became a defining feature of ISIs, as well as an important point of (ideological and strategic) contention between it and al-Qā'ida.

The issue of religious and political significance of bay'a has fiercely been debated between al-Q̄āida and IsIs affiliates, especially prior to and during the factional infighting since the end of 2013. Sami al-Uraydi, an earlier al-Qāida affiliate and the former deputy leader of Organisation for the Liberation of Syria (Hayāt Tahrīr al-Shām), defines allegiance as both general (bay'at al-ämma) and specific (bay'at al-khāșsa). The former concerns the public, which is obliged to recognise the political authorities in exchange for the political leadership's obligation to protect it. If the political authorities fail to do so, the political leadership becomes illegitimate.

The latter expression concerns the obligation to fight the umma's apparent enemy with all that that entails. 'Azzāms writings make a similar distinction between the collective ( fard kifāya) and individual (fard 'ayn) duty to fight. This type of legal reasoning reduces the general scope of al-Qā'ida's initial understanding of general allegiance to the mere recognition of an individual's 
belonging to the ummah, an expression of one's Muslim identity, as it were ('Azzām 1985).

The fourth generation of violence-oriented takfiri activists, in the shape of IsIs have a different understanding of belonging to a Muslim community. For IsIs, a Muslim's identity is conditioned upon his or her active theological and political allegiance to and recognition of the caliphal authority. This makes its notion of takfir broader than that of al-Qācida and its affiliates. More significantly, IsIs leadership's reasoning is premised on a theological methodology that likens one's religious creed ('aqida) with political recognition (bay'a) and unquestionable obedience (sa'ah wa țácah) to the ruler (khalîfa) and what is understood as godly political order (khiläfa or imāma). Therefore, 'correct' political allegiance, bay'a, much like 'aqìda, is an essential condition for salvation. ${ }^{6}$ Subsequently, ISIs' theological methodology directly implies that each believer is expected to actively demonstrate and confirm his or her enmity to all other political orders and/or persons, be they branded as țaghüt, käfir, or murtad, to be accepted as a mu'min (believer).

Next, consider the context - the so-called Sunnì Awakening in Iraq (20062010) - within which such a theological methodology gained traction. During this period, large swaths of the Sunnī minority rebelled against the sectarian Iraqi state institutions occupied almost exclusively by Shīiss. Systematic disenfranchisement of Sunnīs after Saddam Hussein's fall in 2003 contributed directly to the domestic growth of takfiri-oriented militancy. Likewise, the occupying forces' policies had intensified sectarian identity politics to the point of a lowintensity civil war. For example, the dismantlement of the former regime's army caused many Saddam-era officers to join the fight against both the occupying forces and the Shīa-dominated government. During this same period, al-Q⿱亠乂冖'ida in Iraq garnered increased material support from part of the disenfranchised Sunnīs living in the country's western provinces (McCants 2015).

The Sunnì tribal leaders' support for AQI after 2010, and later ISIS in 2014, was primarily based on pragmatic calculations concerning their collective survival in an increasingly violent sectarian context, and not necessarily the population's theological convictions (Gerges 2016). The effects of this alliance of convenience were immediate. The pre-existing road, electricity, water, oilproducing infrastructures were quickly utilized by experienced IsIS managers who had built a self-sustaining bureaucracy that, in turn, enabled the enforcement of strict public morality codes. Moreover, its attempt to establish a new order included the theatrical destruction of cultural heritage that did not

6 See Dabiq 2014, 1: 6-7, also the article on Imāma, July 2014: 20-28. 
conform to its religious interpretations, ${ }^{7}$ redolent of al-Zarqawi's targeting of Shīa places of worship (McCants 2015: 99ff.). Due to the deepening sectarian conflict and prolonged war without any prospects of peaceful settlement, the evolving violence-oriented takfirù mobilization allowed no space for any deviance from the strict doctrines of radical differentiation between friends (believers) and enemies (heretics). In a war situation, one can assume various drastic notions of cosmic war, such as the Isis apocalyptic framework's disallowance of any doctrinal, tactical, or otherwise nuances. A totalizing, black-and-white, and unrestrained worldview becomes a realistic dogmatic alternative. In other words, the immediacy of survival, wherein the logic of total war mixed with questions of survival and even salvation, became the defining feature of political discourse (Kalyvas 2006).

\section{$7 \quad$ The Case of ISIS and its Theology of 'Apocalypse Now'}

In a narrow historical sense, the Islamic State in Iraq and Syria (ISIS), or Dawla al-Islāmiyya fĩ al-Iraq wa Shām (Daesh), can be considered an outgrowth of the theological and organisational evolution of al-Qā'ida's network in Iraq after the US invasion of 2003. ISIs, which briefly controlled large swaths of territory in eastern Syria and western Iraq, represents a transnational takfirist network that seeks to establish a new theocratic state. Self-identified as a caliphate (khiläfa), it is based on the idea of global and perpetual war, a takfiri credo, and an apocalyptic worldview. This also means that Isis is a tactically, ideologically, and religiously violent movement that had operated in several Muslim-majority authoritarian and failed states within which it exerted varying degrees of control over part of their territory.

ISIS represents an early twenty-first century wave of violence-oriented takfirism that differs from similar historical groups. Its theological underpinning is rooted in an eschatological conviction that initiating a global conflict between Muslims and non-Muslims and "re-establishing" the khiläfa marks the beginning of the Day of Judgement. Members urge their audiences

7 Some of the most reported cases in this regard is the group's total destruction of ancient Palmyra's Temple of Bel and its Roman amphitheatre, among other things, reminiscent of the Taliban's 2001 destruction of the Buddha statues in Afghanistan's Bamiyan valley. ISIS also destroyed a large number of historical mosques in the Syrian and Iraqi land that it controlled, purportedly because they symbolised shirk (polytheism) (Dabiq 2:14-17). ISIs' defiance against the international and national plies to stop destroying the historical monuments attracted the mainstream media's attention which was arguably the very purpose of the material destruction. 
to participate in a cosmic struggle between good and evil. This messianic project is oftentimes expressed in a symbolic and tangibly violent rhetoric of religious and political othering and excommunication, but also in mass-killings and destruction of property. This analysis highlights the interchangeably of some of the important political and theological elements found among its core building blocks. IsIS can therefore be considered to represent an outgrowth and ideological creation of combining contextual circumstances dominated by authoritarian rule and violent foreign interventions, intra-state conflicts, long-running zealous doctrines of sectarian othering, and radical and politically motivated groups (Hafez 2003). Over the last fifty years, violenceoriented takfirism, as previously explained, has undergone evolutionary stages represented by a particular generation of militants who responded to unique circumstances.

As elaborated above, the first stage (not to be confused with generation), characterised by the rise of violence-oriented ideological and religious belligerency, was triggered by the persistence and perceived robustness of repressive and totalitarian states in the post-colonial MENA region. Authoritarianism there, especially in Egypt during the 1950s and 196os, helped form the first takfir-centred organisation - Jamā'at al-Muslimīn - in 1969, which the Egyptian media labelled Takfir wa al-Hijra (Excommunication and Emigration) several years later. This initially nonparticipating and isolationist religious group considered the Egyptian state, its society, and the wider Muslim community as heretical and fallen in terms of their religious duties. Its leaders therefore excommunicated (takfir) all non-members and those who rejected their views and religious understandings. The second stage represents the particular expressions of marginal, yet still important, violent mobilization in that region during the 1970 and 198 os, which was (in)directly prompted by the Soviet occupation of Afghanistan. Its leaders produced key takfirì(-oriented) texts. The third generation, which arose during the 199os, represents the internationalization and broadening of violence-oriented takfiri mobilization, which culminated with the $9 / 11$ attacks on the US symbols of political and economic power.

The fourth stage was initiated by the US-led invasion and subsequent occupation of Afghanistan (2001-2014) and Iraq (2003-2014), which provided pivotal political opportunities for the evolution of an increasingly religiously and politically independent strand of takfirist militancy. This stage started in the beginning of the 2010s, when the so-called Arab Spring destabilised several authoritarian regimes, thereby creating unprecedented opportunities to establish themselves in previously impervious territories, most notably Libya and Syria. IsIs launched a massive recruitment drive that has attracted many young, frustrated, and almost exclusively male volunteers from 
the MENA region, Europe, Asia, and Africa. They, together with parts of the deprived and disenfranchised Iraqi and Syrian rebels, made up its core fighting force. The leaders framed these important consolidating factors within their state-building project, which pivots around apocalyptic interpretations of existing takfiri doctrines, thereby adding a powerful theological spin to its millenarian worldview.

In the war-torn Iraq and later Syria during the 2010s, the pre-existing and marginal religious imaginaries and symbols had become weaponised rhetorical tools that often demean, dehumanize, and dishonour the perceived enemy. These have been tangible in both al-Qāiida and Isıs narratives, which are replete with 'otherising' terms: kuffär, deviants, hypocrites, innovators, heretics, crusaders, Zionists, and so on. ${ }^{8}$ The assumed logic of war and enmity, especially in civil conflicts, had produced a sense of immediacy wherein the individual is obliged to show enmity to anyone who does not subscribe to or share his or her (political, ideological, religious and so forth) convictions (Kalyvas 1999). Extraordinary displays of enmity and violent forms of theological hair-splitting are more common during periods of prolonged and collective existential crises (Taylor 2013). Severe forms of existential stress, especially in war situations, enable the growth of particularly violence-oriented and anti-systemic groups.

Propaganda materials effectively communicate an alternative reality that can perpetuate enmity and encourage violence. For example, Dabiq was a major ISIS news outlet for personal interviews of its fighters and commanders, as well as expositions of its doctrinal principles. The magazine hurled many proclamations of takfir against 'non-conformist' Muslims, "renegades whom it's permissible to fight, and for no reason other than the fact that they refuse to give bay 'a" (Dabiq 2014, 1:24). The political and theological notions of hākimiyya and political allegiance are equated with the correctness of one's religious creed and 'purity of faith', which subsequently assumed the central theological place in differentiating friend from enemy.

In the eighth issue of its English-language version, an article entitled "Irjä, the most dangerous bid'a: ${ }^{9}$ and its effects on the jihād in Sham [Syria]" presents IsIS' eighteen-page opposition to considering all Muslims to be believers as a default position or based on their own words and statements. The

8 This type of hostile othering and categorizing is similar to that used in the occasionally racist labelling of perceived enemies as terrorists, jihadists, extremists, Mohammedans, Islamists, hajjis, camel jockeys, and so on.

$9 \operatorname{Irja}$ ' (postponing, for example, a judgement) describes a specific theological principle: a person can either have faith or not. The definition of faith is thereby limited to a religious state (of presence or non-presence of faith). In other words, only God can assess the quality of an individual's faith and devotion. It is believed that this assessment will take place on the Day of Judgement. 
article presents several prophetic statements that highlight the importance of one's faith and deeds, followed by contemporary examples of how 'misguided' al-Qā'ida and its allies in Syria are in terms of their military cooperation against ISIS and the Assad regime. In other words, any group or faction that does not back up its ideological beliefs and religious interpretations with proper action, namely, recognising ISIS as the only religiously valid group defending MENA and the world's Muslims, are deviants, heretics, and kuffär-legitimate targets.

ISIs' doctrinal and mobilisation logic, much of which aligns with the early Khārijite theological framework and later takfirì conceptualizations of the political, dictates that it represents the only legitimate solution to the entire spectrum of socio-political, moral, and economic problems experienced by the global Sunni population. This logic, therefore, extends to claiming that the organization has an exclusive God-given right to establish the eschatologically ordained and sole legitimate power structure recognised by God, namely, the caliphate (Dabiq 2014: 1). Within the scope of IsIs' political theology and God's sovereignty, its general framework of religious creed, acts of political loyalty and disavowal, including strict adherence to moral piety, are combined with one's obligatory allegiance to the self-proclaimed Caliph Ibrahim Awad Ibrahim alBadri al-Samariai, or simply Abu Bakr al-Baghdadi (assassinated 2019).

A large number of Sunnī scholars and religious movements have heavily criticised the IsIs' policies and religious standpoints on a range of issues, including the legitimation of slavery and its millenarian interpretations. ${ }^{10}$ At the same time, the IsIs leadership challenges the validity of any religious and political authority outside its own power structure of ideological control. In the fourth issue of Dabiq carried "The Revival of Slavery before the Hour," which argued for the systematic enslavement of Yezidi individuals and prisoners of war, particularly women, so that the group's fighters could avoid committing sexual "sins":

[T] he Yezidi women and children were then divided according to the sharia amongst the fighters of the Islamic State who participated in the Sinjar operations, after one fifth of the slaves were transferred to the Islamic State's authority to be divided as khums.

Dabiq 2014, 4:15

Some Salafis, including ISIS, regard bid'a as a negative form of innovation in matters of religion. This term therefore describes an attempt to deform Islam's teachings and thus threatens IsIs' strict understandings of the religious sources.

10 Some criticism is presented at http://www.lettertobaghdadi.com/. For more theologically based Sunnī criticisms, see al-Yaqoubi (2015). 
This interpretation provides religious justification for the legitimacy of slavery as a part of war booty. ${ }^{11}$ What is more, enslavement seems to be based on the Yezidis' supposed belonging to an ancient "pagan minority" having the sole legal status of a subservient class of people. Another consequence of this attitude is its genocidal policies justified as a revenge for "genocide [that] is committed by the Maliki, Asadi, and Israeli forces against the Muslims via systematic massacres, chemical warfare, rape, and starvation by siege, Obama watches with euphoria" (Dabiq 2014, 3:35).

Another eschatological passage relates its revival as a precondition of the Day of Judgement:

After this discussion and as we approach al-Malhamah al-Kubrā (the greatest battle before the Hour [Armageddon])—whenever its time comes by Allāh's decree-it is interesting to note that slavery has been mentioned as one of the signs of the Hour as well as one of the causes behind al-Malhamah al-Kubrā.

Dabiq 2014, 4:15

Yet another argument regarding slavery is connected to takfir. Expecting the critique from the "weak-minded and weak hearted," presumably the Muslim public and religious establishment, the article justifies the "revival of slavery" as a preordained and God-given obligation:

Before Shaytān [Satan] reveals his doubts to the weak-minded and weak hearted, one should remember that enslaving the families of the kuffär and taking their women as concubines is a firmly established aspect of the sharīa that if one were to deny or mock, he would be denying or mocking the verses of the Qur'ann and the narrations of the Prophet (sallallähu 'alayhi wa sallam), and thereby apostatizing from Islam.

Dabiq 2014, 4:14

11 Many Sunnī scholars have issued fatwās refuting IsIs' claims of legitimacy for slavery and its other religious interpretations (Al-Yaqoubi 2015, www.lettertobaghdadi.org, Dar al-Ifta). "Egypt's Dar al-Iftaa vehemently condemns the heinous murder of the Jordanian pilot by the bloodthirsty Qsis." Al Azhar Fatwā Committee Official Website, at http://eng .dar-alifta.org/foreign/ViewArticle.aspx?ID=66o\&CategoryID=1. Accessed o1/o6/2019. See also Adam McCoy and Adam Taylor, 2015, "Islamic State says immolation was justified: experts on Islam say no," The Washington Post at https://www.washingtonpost .com/news/morning-mix/wp/2015/o2/o4/the-chilling-reason-the-islamic-state-burned -a-jordanian-pilot-alive/. Accessed o1/o6/2019. 
This indicates that the ISIs' strategy of othering and its theological reasoning is extreme in relation to existing Muslim scholarship, from which it radically diverges in terms of current legal understanding of slavery's prohibition ${ }^{12}$ and its understanding of who is a Muslim. ${ }^{13}$ This line of theological reasoning is similar to that of the pre-modern Khārijites. For instance, the above passage suggests that anyone who denies the (Islamic) legality of slavery is per definition a käfir. The same article directly suggests that in a literal interpretation of the scriptures, slavery is "much more plausible" than any other interpretations (see above). This apparent melding together of $u s \underline{u} l \bar{\imath}$ (the basic theological principles) and furü (legal rulings) is another methodological similarity with the early Khārijites and dissimilarity with contemporary mainstream Sunnīsm. ${ }^{14}$

\section{8}

\section{Conclusion}

ISIS is the latest evolutionary stage of violence-oriented takfiri-based mobilization that denotes a religiously inspired socio-political ideology that has spawned a militant organisation with a sustained, distinct, and largely unique set of millenarian beliefs and violent practices. This set of religious and political beliefs has gained traction in the context of existing national and international violent conflicts and, as such, has been conveyed through a range of violent and extraordinary forms of othering. Its particular violence-centred religious orientation is takfirist political project that is based on the fusion of narrow, Khārijite-like political strategy and selective, Salafi-inspired, principles of violent othering. In the end, what emerges from this inimitable set of religious, ideological, strategic, and contextual fusions is a worldview driven by the cosmic struggle between perceived believers (ISIs members) and all others.

12 See for example, "Universal Islamic Declaration of Human Rights," 21 Dhul Qaidah 1401/19 September 1981, Preamble, paragraph g), point iii) at http://www.alhewar.com/ ISLAMDECL.html. Accessed o1/o6/2019.

13 See for example, "The Amman Message" at http://ammanmessage.com/. Accessed o1/o6/ 2019 .

14 Mainstream Sunnīsm is a contested term; nevertheless, it is useful because it illustrates numerous points of theological, legal, philosophical, spiritual, and political conflict between ISIS and its many Sunnī opponents, arguably the mainstream. Moreover, the earlier mentioned religious declarations of opposition to IsIs, its religious and political goals and methods, represent just a few English-language examples that outline generally held Sunnī position towards contemporary violence-oriented takfirism in general, and towards IsIs in particular. 


\section{References}

Abou El Fadl, K. 2001. Rebellion and Violence in Islamic Law. Cambridge: Cambridge University Press.

Adang, C. and H. Ansari (ed.). 2015. Accusations of Unbelief in Islam: A Diachronic Perspective on Takfir. Leiden: Brill.

Al-Hudaybi, H. 1977. Du'āt, lā Quḍāt [Missionaries, not Judges]. Cairo: Dar al-Fikr al-'Arabi.

Al-Maqdisi, A.M. 1984. Millat Ibrāhìm wa-Da'wat al-Anbiyā' wa-l-Mursalīn (The Path of Abraham and the Call of the Prophets and Messengers). At https://web.archive .org/web/20100226055120/http://www.tawhed.ws/r1?i=1394\&x=iti4u3zp. Accessed $12 / 12 / 202 \mathrm{O}$.

Al-Mawardi. 1996. The Ordinances of Government [Al-Aḥkām al-Sulțāniyya w'al-Wilayāt al-Diniyyah]. Trans. W.H. Wahba. Reading: Garnet Publishing.

Al-Qahtani, M.S. 2003. Al-Walä’ wal Barä' fil Islām min Mafāhìm 'Aqìdah al-Salaf (Loyalty and Disavowal in Islam according to the Understanding of the Creed of the Pious Predecessors). Cairo: Al-Maktabah al-Tawfiqiyah.

Al-Shahrastani, M. 1923. Kitāb al-milalwa al-nihal (Book of Religious and Philosophical Sects). Ed. Willian Cureton. London: The Society for the Publication of Oriental Texts.

Al-Yaqoubi, M. 2015. Refuting ISIS: A Rebuttal of Its Religious and Ideological Foundations. Virginia: Sacred Knowledge Press.

'Azzām, A. ca. 1985. Defending the Muslim Lands Is among the Most Important Collective Obligations (Al-Difā' 'an Arāḍ̄ al-Muslimìn: Ahamm Furụ̣̄ al-A'yān) (Tawhīd wa al-Jihād). N.p.

Bergen, P.L. 2006. The Osama bin Ladin I Know: An Oral History of al-Qaeda's Leader. New York: Free Press.

Celso, A.N. 2015. “Zarqawi's Legacy: Al Qaeda's ISIS 'Renegade'." Mediterranean Quarterly. 26:2, 21-41.

Chaliand, G., and A. Blin (eds). 2007. The History of Terrorism: From Antiquity to alQaeda. London: University of California Press, Ltd.

Cook, D. 2011. "Jihad and Martyrdom in Classical and Contemporary Islam." In A.R. Murphy ed., The Blackwell Companion to Religion and Violence. Oxford: Blackwell.

Deringil, S. 2000. “There Is No Compulsion in Religion': On Conversion and Apostasy in the Late Ottoman Epire: 1839-1856." Comparative Studies in Society and History. 42:3, 547-575.

El-Rouayheb, K. 2015. Islamic Intellectual History in the Seventeenth Century: Scholarly Currents in the Ottoman Empire and the Maghreb. Cambridge: Cambridge University Press. 
Faraj, M.A.S. 1986. “The Neglected Duty." In J.J.G. Jansen trans., The Neglected Duty: The Creed of Sadat's Assassins and Islamic Resurgence in the Middle East. New York: Macmillan.

Faraj, M.A.S. 200o. Jihaad: The Absent Obligation. Birmingham: Maktabah Al Ansaar.

Farrall, L. 2011. "How al Qaeda Works: What the Organization's Subsidiaries Say about Its Strength." Foreign Affairs. 90, 128-138.

Gerges, F.A. 2009. The Far Enemy: Why Jihad Went Global. 2nd ed. Cambridge: Cambridge University Press.

Gerges, F.A. 2016. ISIS: A History. Princeton: Princeton University Press.

Gunaratna, R. 2002. Inside Al Qaeda: Global Network of Terror. New York: Columbia University Press.

Hafez, M. 2003. Why Muslims Rebel: Repression and Resistance in the Islamic World. London: Lynne Reiner Publishers.

Hamid, M. and L. Farrall. 2015. The Arabs at War in Afghanistan. London: Hurst \& Co.

Hegghammer, T. 20o9. "Jihadi-Salafis or Revolutionaries? On Religion and Politics in the Study of Militant Islamism." In R. Meijer ed., Global Salafism: Islam's New Religious Movement. London: C. Hurst \& Company.

Hodgson, M. 1974. The Venture of Islam: The Classical Age of Islam. Chicago: Chicago University Press.

Hourani, A. 1970. Arabic Thought in The Liberal Age: 1798-1939. Oxford: Oxford University Press.

Huwaidi, F. 1988. Azmat al-wa iy al-dīn̄̄ (Crisis in Religious Consciousness). San'a: Dar al-Hikma al-Yamaniyya.

Ibrahim, R. 2007. The Al Qaeda Reader. New York: Random House.

Kalyvas, S.N. 2006. The Logic of Violence in Civil War. Cambridge: Cambridge University Press.

Kalyvas, S.N. 1999. "Wanton and Sensless? The Logic of Massacres in Algeria." Rationality and Society. 11:3, 243-285.

Kenney, J. 2006. Muslim Rebels: Khārijites and the Politics of Extremism in Egypt. Oxford: Oxford University Press.

Kepel, G. 20o6. Jihad: The Trail of Political Islam. London: I.B. Tauris.

Khalidi, M.A. (ed.). 2005. Medieval Islamic Philosophical Writings. Cambridge: Cambridge University Press.

Khatab, S. 2011. Understanding Islamic Fundamentalism:The Theological and Ideological Basis of al-Qa'ida's Political Tactics. Cairo: The American University in Cairo Press.

Lawrence, B. (ed.). 2005. Messages to the World: The Statements of Osama bin Lädin. Trans. James Howarth. New York: Verso.

Lewis, B. 1988. The Political Language of Islam. Chicago: Chicago University Press. Maher, S. 2016. Salafi-Jihadism. The History of an Idea. Oxford: Oxford University Press. 
Makdisi, G. 1981. The Rise of Colleges: Institutions of Learning in Islam and the West. Edinburgh: Edinburgh University Press.

Naji, A.B. 2006. The Management of Savagery: The Most Critical Stage Through Which the Umma Will Pass. Translated by W. McCants. Cambridge, Mass.: Institute for Strategic Studies.

Quțb, S. 1990. Milestones. Indianapolis: American Trust Publications.

Poljarevic, E. 2012. Exploring Individual Motivation for Social Change: Mobilization of the Muslim Brotherhood's Youth in Pre-revolutionary Egypt. Florence: European University Institute.

Poljarevic, E. 2018. “Jihad." In A. Sharma ed., Encyclopedia of Indian Religions. Islam, Judaism, and Zoroastrianism. Dordrecht: Springer Reference.

Roy, O. 1995. Afghanistan: From Holy War to Civil War. Princeton: Princeton University Press.

Taylor, C.C. 2013. "Genocide and religion Imaginary in Rwanda." In M. Jerryson, M. Juergensmeyer, and M. Kitts eds, The Oxford Handbook of Religion and Violence. Oxford: Oxford University Press.

Voll, J.O. 1982. "Wahhabism and Mahdism: Alternative Styles of Islamic Renewals." Arab Studies Quarterly. 4:1/2, 110-126.

Wagemakers, J. 20o9. “The Transformation of a Radical Concept: Al-Wala' wal Bara' in the Ideology of Abu Muhammad Al-Maqdisi." In R. Meijer ed., Global Salafism: Islam's New Religious Movement. London: C. Hurst \& Company.

Wright, L. 2006. The Looming Tower: Al-Qaeda and the Road to 9/11. New York: Random House. 